\title{
Augmenter of Liver Regeneration: Its Place in the Universe of Hepatic Growth Factors
}

\author{
Antonio Francavilla, ${ }^{1,3}$ Michio Hagrya, ${ }^{2}$ Kendrick A. Porter, ${ }^{1,4}$ Lorenzo Polimeno, ${ }^{1,3}$ IzUmi IHara ${ }^{2}$ \\ AND THOMAS E. STARZL ${ }^{1}$ \\ ${ }^{1}$ The Pittsburgh Transplant Institute, University of Pittsburgh Medical Center, Pittsburgh, Pennsylvania 15213; ${ }^{2}$ Toyobo \\ Company, Ltd., Ohtsu, 520-22 Shiga, Japan; ${ }^{3}$ the Department of Gastroenterology, University of Bari, 70100 Bari, Italy; and ${ }^{4}$ the \\ Department of Experimental Pathology, St. Mary's Hospital and Medical School, London WC1 B3SL, W2, United Kingdom
}

As every school child knows, chameleons can regenerate a lost tail. Indeed, regrowth of appendages is a not uncommon phenomenon among other lower animals. In mammals, however, regenerative capacity is much more restricted. The special regenerative capability of the mammalian liver has been recognized over millennia, as epitomized by the ancient legend of Prometheus. The explanation for liver regeneration has been of interest to investigators for more than a century. With the convergence in our laboratory of two lines of inquiry more than a third of a century ago, this quest for understanding received a major stimulus.

The first theme concerned the cross regulation of the liver and nonhepatic splanchnic organs, especially involving insulin in the pancreaticohepatic axis (1-3). In experiments with Eck's fistula (portacaval shunt), the liver's first pass exposure to the hormone and nutrient-rich venous blood coming from all of the other splanchnic organs was eliminated. Liver atrophy already was well-known to be caused by this operation (4), but was generally ascribed to reduction in total hepatic blood flow, rather than to the loss of a particular kind of blood. Although this "flow hypotheses" of portal physiology was established dogma well into the 1960 s, proving or disproving it was quite another matter. In 1961, after a

Received February 28, 1994; accepted April 25, 1994.

Other abbreviations used in the text: $\mathrm{AcrF}_{4}$, acrylamide fraction 4; ALR, augmenter of liver regeneration; cDNA, complementary deoxyribonucleic acid; EGF, epidermal growth factor; ERV1, essential for respiration and viability; $\mathrm{FKBP}_{12}, \mathrm{FK}$ binding protein; FPLC, fast protein liquid chromatography; HGF, hepatocyte growth factor; HSS, hepatic stimulatory substance; IGF II, insulin-like growth factor; mRNA, messenger ribonucleic acid; ODS, octadecyl silica; RPM, rapamycin; TGF- $\alpha$, transforming growth factor-alpha; TGF- $\beta$, transforming growth factor-beta.

This study has been supported by Research Grants from the Veterans Administration, Project Grant DK 29962 from the Institutes of Health, Bethesda, Maryland, and by Consiglio Nazionale delle Ricerche, ACRP Program, grant number 93-2166-PF39.

Address reprint requests to: Antonio Francavilla, M.D., Veterans Administration Medical Center, University Drive C, Building 6, Room 110, Pittsburgh, PA 15240.

Copyright (c) 1994 by the American Association for the Study of Liver Diseases.

$0270-9139 / 94 \$ 3.00+0 \quad \mathbf{3 1} / \mathbf{1} / \mathbf{5 8 1 8 2}$ lifetime of largely futile examination of the subject, Bollman (5) wrote, "In the 83 years since it was first reported, the Eck fistula has been reasonably successful in hiding its secrets as well as giving rise to many additional questions fundamental to an understanding of the functions of the intestine, liver and brain."

The canine Eck fistula investigations coalesced with our second research theme of liver transplantation in experiments to determine in dogs the optimum anatomic positioning and revascularization of orthotopic (6) or auxiliary hepatic allografts (7). Provision of a normal portal blood supply was shown to be important with either kind of transplant procedure, but uniquely so with the auxiliary hepatic operation after which two livers coexisted in the same dog (Fig. 1A). It was found that the organ through which host splanchnic venous blood was directed retained its normal size, whereas the competing organ (whether host or graft) shrank and deteriorated functionally, in spite of providing it with portal venous inflow from alternative nonsplanchnic sources $(7,8)$. The shrunken portaprival liver (Fig. 2) showed other characteristics that were indistinguishable from an Eck fistula liver. We concluded that there must be growth-modulating substances in splanchnic venous blood that controlled the liver's size and presumably the quality of its function.

These substances came to be known as hepatotrophic factors and, although they remained unidentified for another $10 \mathrm{yr}$, it was clear that they were largely consumed during a single passage through the first liver to which they were exposed, leaving little for its atrophic partner. Recognition of the double liver principle, whereby one liver dominates the other by its avid clearance of hepatotrophic factors, subsequently had a pervasive impact on the study of liver physiology in general and hepatic growth factors in particular, but this was slow to evolve. In extensions of the primary discovery, a series of nontransplant models was developed (9-11) in which the animal's own liver was divided into competing fragments (Fig. 1B-D). With these models, and particularly the final one shown in Figure 1D (see later), eight growth factors with potent hepatotrophic effects (11-21) as well as two with 


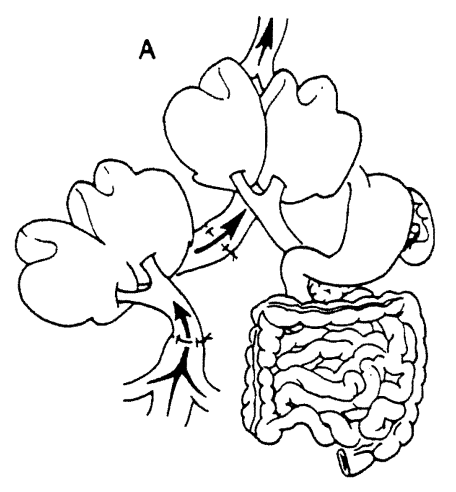

B
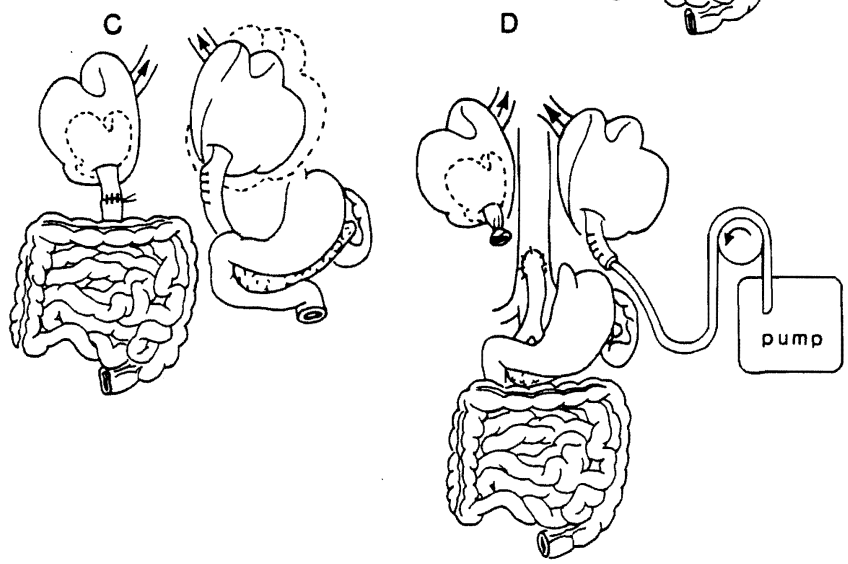

FIG. 1. Growth factor detection with coexisting liver and Eck fistula models alone or in combination: (A) auxiliary liver transplantation; (B) partial portacaval transposition; (C) splanchnic venous division; (D) Eck fistula plus selective infusion of tested substance.

the opposite action $(22,23)$ were identified (Table 1).

The first clearly delineated hepatotrophic factor was insulin (11), followed $4 \mathrm{yr}$ later (12) by the cytosol of liver cells containing the ALR, which is the principal focus of this review. When infused by itself into the defunctionalized hilar portal vein after portacaval shunt, each of the eight substances could prevent the hepatocyte and whole organ shrinkage caused by the Eck fistula. In addition, they all caused a hyperplastic response similar in amplitude but more sustained than in the regeneration response following a moderate partial hepatectomy. The development of the in vivo Eck fistula assay (Fig. 1D) was critical for the identification and study of these eight hepatotrophic factors because only two of them, TGF- $\alpha$ and HGF, stimulate mitoses in tissue culture.

The most elusive of the six nonmitogenic "occult" growth factors was the ALR, of which there was evidence in the hyperplastic livers of weanling rats, or in the residual liver fragment of adult animals of several species after partial hepatectomy. Its purification to $>800,000$ (13-16) and cloning (17) after $16 \mathrm{yr}$ of continuous effort in our laboratories has added another important component to the complex network of modulators, both stimulatory and suppressive, that regulate hepatocyte proliferation and hepatic regeneration at the organ level. In these days of cellular and molecular biology, it is striking that the two operations of portacaval shunt (Eck's fistula) (24) and auxiliary liver transplantation (25) described in dogs $78 \mathrm{yr}$ apart played an indispensable role in this development.

The new growth factor ALR is a unique heat-stable peptide whose gene exhibits a 50\% homology with the dual-function nuclear yeast gene ERV1 (17). The ERV1 gene is required for oxidative phosphorylation (respiratory chain) and is essential for mitosis, which ceases in 3 to 4 days after gene deletion in Saccharomyces cerevisiae (26). If, as we suspect, ALR is the mammalian homolog of ERV1, it is apt to be a major growthregulatory gene.

Just as an understanding of the regulation of bone marrow proliferation by lineage-specific hematopoietic growth factors has led to major advances in the safety and success and significant reductions in the cost of bone marrow transplantation (27-29), a similar understanding of the regulation of hepatocyte proliferation and hepatic regeneration will have immediate applications in numerous clinical settings. These could include the treatment of fulminant hepatic failure, and complications of hepatic surgical procedures including both portasystemic shunt operations and transplantation. The ability to influence hepatic mitotic activity and the cell cycle may also dramatically influence the choices of strategies for hepatic gene therapy, some of which currently require surgical partial hepatectomy to induce the necessary hepatocyte proliferation (30).

In the sections that follow, we review the pathophysiology of the often-maligned Eck fistula and emphasize the unique role it has played in the search for and study of hepatocyte growth-regulatory factors. We will then attempt to place ALR in an appropriate perspective in the expanding universe of hepatic growth factors.

\section{THE PATHOPHYSIOLOGY OF ECK'S FISTULA}

The Eck fistula liver after portacaval shunt was thought-until about 30 yr ago-to function normally except for hyperammonemia. This view was inconsistent with the striking hepatocyte atrophy (to half size), deglyogenation and fatty infiltration caused by the operation in all species studied, including human beings (31-34). At the same time, there is a tripling of liver cell renewal $(11,34,35)$. In dogs, both the atrophic and hyperplastic alterations are complete within 4 days and remain stable thereafter (Table 2). The ultrastructure of the hepatocytes shows a striking disruption of the rough endoplasmic reticulum and depletion of the ribosomes $(12,31-38)$, explaining a reduced synthesis of cholesterol and other lipid moieties, bile acids, urea and, presumably, essentially all metabolites of hepatic origin (summarized in reference 33). Lowered activity of the hepatic microsomal mixed function enzyme system for which multiple cytochrome P-450 and P-448 species serve as terminal oxidases account for other subtle but cumulatively massive degradations in hepatic function (33). 


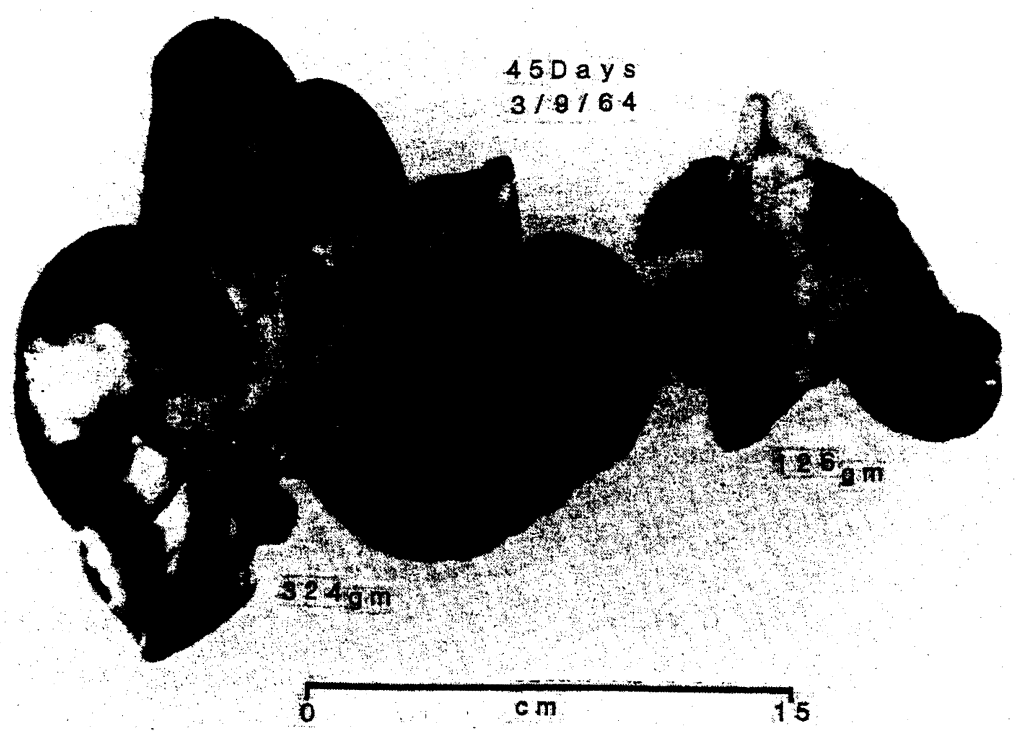

FIG. 2. The auxiliary allograft (right) and the recipient dog's own liver (left) 45 days after the experimental transplantation was performed in 1964. Immunosuppression was with azathioprine, and there was no histopathological evidence of rejection. Note the well-preserved but dimensionally reduced general structure of the allograft. The gallbladder did not shrink proportionately: (By permission of Starzl TE, et al. Ann Surg 1964;160:411-438.)

TABLE 1. Growth factors revealed by studies in Eck fistula models (1994)

\begin{tabular}{lc}
\hline & Reference no. \\
\hline Stimulatory & \\
Hormones: & 11 \\
Insulin & \\
Growth factors: & $12-17$ \\
Cytosol substrate and ALR & 18 \\
IGF II & 18 \\
TGF- $\alpha^{\alpha}$ & 18 \\
HGF & \\
Immunosuppressants: & 19 \\
Cyclosporine & 20 \\
FK 506 & \\
Immunophilins: & 21 \\
FKBP & \\
Inhibitory & \\
Growth factors: & \\
TGF $\beta^{b}$ & 22 \\
Immunosuppression: & 23 \\
Rapamycin & \\
\hline
\end{tabular}

${ }^{a}$ Mitogenic in tissue culture.

${ }^{b}$ Inhibitory in tissue culture.

\section{THE DOUBLE LIVER FRAGMENT MODELS}

The evidence of portal hepatotrophic factors obtained in the 1963 auxiliary liver transplant experiments was verified in nontransplant models developed over the next decade in which the animal's own liver was divided into two fragments, differing in the quality of blood delivered to the right and left main portal vein branches. The flow hypothesis of portal physiology that already had been toppled was now routed by a series of complex double liver fragment experiments showing that the least hepatotrophic blood was that from the inferior vena cava $(9,10)$ (Fig. 1B), and the most hepatotrophic was from
TABLE 2. Evolution of Eck fistula changes after operation

\begin{tabular}{ccc}
\hline Time in days & $\begin{array}{c}\text { Labeled } \\
\text { hepatocytes } \mathbf{1 , 0 0 0}\end{array}$ & Cell size units \\
\hline 0 & 1.5 & 0.18 \\
1 & 1.5 & 0.17 \\
2 & 1.9 & 0.15 \\
3 & 3.2 & 0.12 \\
4 & 4.5 & 0.09 \\
60 & 4.5 & 0.09 \\
\hline
\end{tabular}

Composite references: $11,12,34,36$

the upper splanchnic viscera, which included the pancreas (10, 31, 39) (Fig. 1C). The "liver-supporting"' qualities of the nutrient-rich intestinal venous affluent were between those extremes $(31,39)$ (Fig. 1C). It also was found that the canine liver tissue with first-pass exposure to endogenous insulin had 3 to 4 times the basal cell renewal of the atrophic insulinoprival fragments ( 15 vs. $4.5 / 1,000$ hepatocytes with thymidine incorporation) and a superior ability to regenerate after hepatic resection (36). All of these so-called hepatotrophic advantages were lost after surgical pancreatectomy or the production of alloxan or streptozotocin diabetes $(31,36,39)$. Thus, although insulin was poorly mitogenic-if at all-to hepatocytes in tissue culture (40-42), it was the principal portal hepatotrophic candidate from 1973 onward (10).

\section{THE ECK FISTULA/DOUBLE LIVER ASSAY IN THE HEPATOTROPHIC FACTOR SEARCH}

The dominance of insulin notwithstanding, there was evidence in canine double liver $(31,36,39)$ and selective evisceration experiments $(43,44)$ of other cumulatively significant splanchnic growth factors, principally of intestinal origin. The inability to separate these effects 
from those of insulin, or even to prove that insulin alone was hepatotrophic prompted development of an additional double-fragment canine model $(11,34)$, in which the liver was first deprived of all portal inflow by performing portacaval shunt. Then, an infusion catheter was inserted into a tied-off portal vein branch, and test substances were injected regionally into the vein's distribution. In essence, this created a sophisticated double liver preparation in which the effect of a single agent could be determined in one liver region and its effects judged by comparison with the uninfused (control) side (Figure 1D). The hepatotrophic end points in this growth factor assay were the same as in the other double fragment models: hepatocyte size, rate of cell renewal and quality of ultrastructure.

\section{Hormones}

A potent hepatotrophic effect of insulin was easily demonstrable with the Eck fistula assay $(11,34)$. The emergence of insulin and the demonstration by Short and Lieberman (45) that hormone cocktails could drive resting livers into mitosis prompted a flurry of hormoneregulatory hypotheses to explain hepatic regeneration (45-47), supported by claims that glucagon was synergistic with insulin (48). However, the hypothesis was undermined by the inability to confirm a glucagon effect in the canine Eck fistula model $(11,34)$ or in selective evisceration experiments in dogs $(43,44)$, and by failure with the Eck fistula during the next 15 yr to add more hormones to the list of hepatotrophic molecules with the possible exception of the weakly hepatotrophic thyroxin $\left(\mathrm{T}_{3}\right)(18)$.

In the meanwhile, the demonstration that several hormones and nonhormonal agents were mitogenic to cultured hepatocytes contributed to a switch to in vitro screening technologies $(41,49,50)$ by most investigators in the growth factor field, a consensus movement that we resisted. Warned by our experience with insulin that growth factor potency in vivo and mitogenicity in tissue culture were not correlated, we continued to depend on in vivo testing as the ultimate benchmark in all further growth factor research.

\section{ALR}

With the eclipse of the multiple hormone hypothesis, our attention in 1978 turned upstream to the liver, which had been suspected for a long time to be a source of self-perpetuating paracrine or humoral growth factor(s) (51). Soon after the classic description in 1931 by Higgins and Anderson (52) of hepatic regeneration in rats after $70 \%$ hepatectomy, McJunkin and Breuhaus (53) reported that the modest mitotic response to a limited ( $30 \%$ to $45 \%$ ) hepatectomy was significantly enhanced with an intraperitoneal injection 2 days postoperatively of homogenized homologous rat liver. In Helsinki, Teir and Ravanti (54) and Teir's postgraduate student, Blomquist (55), associated this regenerationaugmenting activity with the heightened mitoses that were in the weanling or regenerating posthepatectomy livers from which their homogenates were made. The mirror image observations also were made that these homogenates were most effective when injected into weanling rats who had naturally hyperplastic livers only equivocally so by 3 mo of age when the hepatic hyperplasia in the test animals had abated, and not at all in adult rats. This meant that mitoses in the donor liver begot hepatic mitoses in the treated animal but only when there was a concomitant or previous commitment to increased cell renewal for independent reasons.

However, this evidence of a need for "priming" was not fully conceptualized until 1975, when LaBrecque and Pesch (56) described "hepatic stimulatory substance (HSS)" in the cytosol of weanling or regenerating rat livers. The HSS did not affect the resting adult liver when injected intraperitoneally, but it significantly augmented the regeneration after a small hepatectomy in these animals. In analogous canine experiments, using regenerating posthepatectomy liver as a cytosol source (57), we confirmed the findings of LaBreque and Pesch. By this time, the relatively crude minimum hepatectomy model to study the stimulatory activity of the liver had survived a half century of scientific literature (53-57). It was one of the two in vivo assays used subsequently to study purified ALR.

The other was the Eck fistula assay, the exquisite sensitivity of which was established during the crucial demonstration in 1979 that dog hepatic cytosol had the same hepatotrophic effects as insulin in this model (12). The stimulatory activity was maximal in the cytosol prepared from hepatic remnants harvested 2 and 3 days after resection $(12,57)$, when peak liver regeneration occurs in the canine species (58). Similar to the rat HSS of LaBrecque and Pesch (56), the canine "X-factor" was heat-stable but destroyed by perchloric acid. The cytosol containing it was rich in soluble proteins and other cytoplasmic constituents, but free of organelles, cell membranes, microsomes, viruses and insulin or glucagon (12).

At an international hepatology congress held in Basel, Switzerland in 1979, the history of hepatotrophic physiology was reviewed, including the latest information about the stimulatory qualities of regenerating hepatic cytosol and announcement of plans for its purification (59). By this time, peer acceptance of the hepatotrophic concept was complete. However, overthrow of the deeply entrenched "flow hypothesis" had taken more than 15 $y r$, leaving scientific corpses and priority disputes in its wake. Most importantly, the consensus movement during this time toward in vitro cellular as well as molecular biological investigative techniques tended to place the previous accomplishments with intact animals in an unsophisticated light. The currents of funding turned cold for proposals to purify liver cytosol and test it along the in vivo lines that had been so fruitful. Consequently, all grant applications for the purification project were rejected by peer review during the next 15 yr, invariably with comments about the nonfeasibility of the proposal in the hands of the applicants. A shutdown was prevented by internal support from the University of Pittsburgh and by the fact that an appendiceal connection could be made to research funding in transplantation. 
TABLE 3. Preparation of rat ALR

\begin{tabular}{|c|c|c|c|c|}
\hline Purification steps & Product & $\begin{array}{c}\text { Times } \\
\text { purification }\end{array}$ & Year & $\begin{array}{l}\text { Initial animal } \\
\text { assay used }\end{array}$ \\
\hline $\begin{array}{l}\text { 1. Killing by guillotine, between } 7: 00 \text { and } 8: 00 \mathrm{AM} \text {. Mince and } \\
\text { then homogenize the liver in } 150 \mathrm{mmol} / \mathrm{L} \text { sodium acetate buffer, } \\
\mathrm{pH} 4.65(35: 100 \mathrm{w} / \mathrm{v}) \text {. } \\
\text { Ultracentrifuge homogenate at } 24,000 \mathrm{~g} \text { for } 30 \mathrm{~min} \text { at } 4^{\circ} \mathrm{C} \text {. }\end{array}$ & Cytosol fraction (Cyt-F) & - & 1982 & Rats \\
\hline $\begin{array}{l}\text { 2. Heat cytosol at } 65^{\circ} \mathrm{C} \text { for } 15 \mathrm{~min} \text {. Centrifuge at } 30,000 \mathrm{~g} \text { for } \\
20 \mathrm{~min} \text { at } 4^{\circ} \mathrm{C} \text {, collect supernatant and add to it } 6 \text { vol of cold } \\
\text { ethanol }(1: 6, \mathrm{v} / \mathrm{v}) \text {. Stir at } 2-8^{\circ} \mathrm{C} \text { for } 2 \mathrm{hr} \text {. Centrifuge } 30,000 \mathrm{~g} \\
\text { for } 20 \mathrm{~min} \text { at } 4^{\circ} \mathrm{C} \text {. Resuspend precipitate in } 0.150 \mathrm{mmol} / \mathrm{L} \\
\text { ammonium acetate } \mathrm{pH}=6 .\end{array}$ & Alcohol fraction $(\mathrm{OH}-\mathrm{F})$ & 32 & 1983 & Rats \\
\hline $\begin{array}{l}\text { 3. Filter } \mathrm{OH}-\mathrm{F} \text { through an Amicon membrane with a molecular } \\
\text { weight cutoff of } 30,000 \mathrm{Da} \text {. } \\
\text { Collect the filtrate and concentrate it by a } 500-\mathrm{Da} \text { cutoff Ami- } \\
\text { con membrane. }\end{array}$ & Mr 30,000 fraction $(30 \mathrm{kDa}-\mathrm{F})$ & 52 & 1983 & Rats \\
\hline $\begin{array}{l}\text { 4. Lyophilize } 30 \mathrm{kDa}-\mathrm{F} \text {. Resuspend lyophilized } 30 \mathrm{kDa}-\mathrm{F} \text { phos- } \\
\text { phate buffer } 5 \mathrm{mmol} / \mathrm{L}, \mathrm{pH} 6 \text {, and perfrom chromatography us- } \\
\text { ing mono Q HR } 5 / 5 \mathrm{column} \text { with a linear } 0-200 \mathrm{mmol} / \mathrm{L} \mathrm{NaCl} \\
\text { gradient in phosphate buffer. } \\
\text { Collect the chromatographic peak at } 150 \mathrm{mmol} / \mathrm{L} \mathrm{NaCl} \text { gradient. }\end{array}$ & 150 fraction $\left(\mathrm{F}_{150}\right)$ & 31,000 & 1985 & Rats \\
\hline 5. Nondissociating PAGE of $F_{150}$ & Acr $\mathrm{F}_{4}$ & 381,000 & 1987 & Rats, dogs \\
\hline
\end{tabular}

${ }^{a}$ Literature of earlier purification steps summarized in reference 14.

Choice of Stimulatory Cytosol. Beginning in the autumn of $1981,8 \frac{1}{2} \mathrm{yr}$ were invested to obtain a pure enough fraction to permit an attempt at sequence analysis and cloning $(13-16,60)$. The rat rather than the dog was selected as a substrate source because the objective was to learn the protein chemistry of the purified active substance. How to induce the hepatic hyperplasia, without which stimulatory activity was not detectable, was the first question. The induction of hepatocyte proliferation with $\mathrm{T}_{3}(13,61)$ or with hepatectomy were eventually discarded because of concern that they would induce hormonal or stress-related artefacts, respectively. In 1984, we switched exclusively to weanling rats ( $<80 \mathrm{gm}, 2$ to $3 \mathrm{wk}$ old) as a cytosol source, as first recommended by Teir and Ravanti (54); eventually more than 10,000 animals were required. Pooling of the naturally hyperplastic weanling livers diluted the effect of isolated errors in animal selection or variations in activity.

Assay. In agreement with the in vitro results of workers elsewhere, the crude cytosol and our earliest fractions increased the thymidine incorporation of cultured hepatocytes or hepatoma cells $(13,61)$. This stimulatory property was retained in the purification products described by LaBrecque et al. $(62,63)$. Fleig and Hoss (64) also reported stimulatory activity of the cytosol refinement products, but only if the medium also was enriched with epidermal growth factor (EGF). In contrast, all fractions prepared by us beyond $\times 30,000$ purification were inert in vitro with or without EGF (14, 15), including the highly purified peptide used for cDNA cloning (17). At the time, the divergence of our results from those of other investigators raised the possibility that we had refined away the molecule we were seeking, but our results ultimately became part of the uniqueness profile of our ALR.
Uncertainties about in vivo assay also bedeviled the research for the first $7 \mathrm{yr}$. In an egregious error, we believed that the highly reproducible canine Eck fistula model would be inappropriate to assay the rat peptide. With the alternative method of LaBrecque and Pesch (56), the variability of the regeneration that normally follows a small ( $34 \%$ to $40 \%$ ) hepatectomy in rats made it difficult to quantitate the augmentation of this response caused by an intraperitoneal injection of rat cytosol or its derivatives.

After species-nonspecificity of the purified cytosol fractions was proved in 1987 (14), we returned to the canine Eck fistula model for assay (15). This ended the nightmare of attempting to purify a growth factor whose growth effects could not be accurately evaluated. Now, we were able to confidently proceed from one stage of purification to the next.

Purification. Details of the purification of ALR, as well as the years in which improvements were made, are summarized in Table 3 . The F150 fraction $(\times 31,000)$ prepared with FPLC was shown to be stable for $>1 \mathrm{yr}$, permitting its stockpiling. However, the entire supply was used up between 1985 and 1987 in futile attempts at further purification, without knowing whether the activity had been discarded or inadequately assayed. In spite of the prodigious effort already made, abandonment of the project was discussed for the first time.

Instead, a fresh start was begun with a newly prepared supply of the lyophilyed F150 fraction, using nondissociating PAGE. Four fractions were produced (Fig. 3), of which $\mathrm{AcrF}_{4}(\times 381,000$ purification $)$ was shown to be active by testing with both the minimal hepatectomy and Eck fistula models (Fig. 4). When the results from these two assays were shown to correlate (15), a bottleneck was broken. With the Eck fistula assay, hepatotrophic activity could be unambiguously iden- 


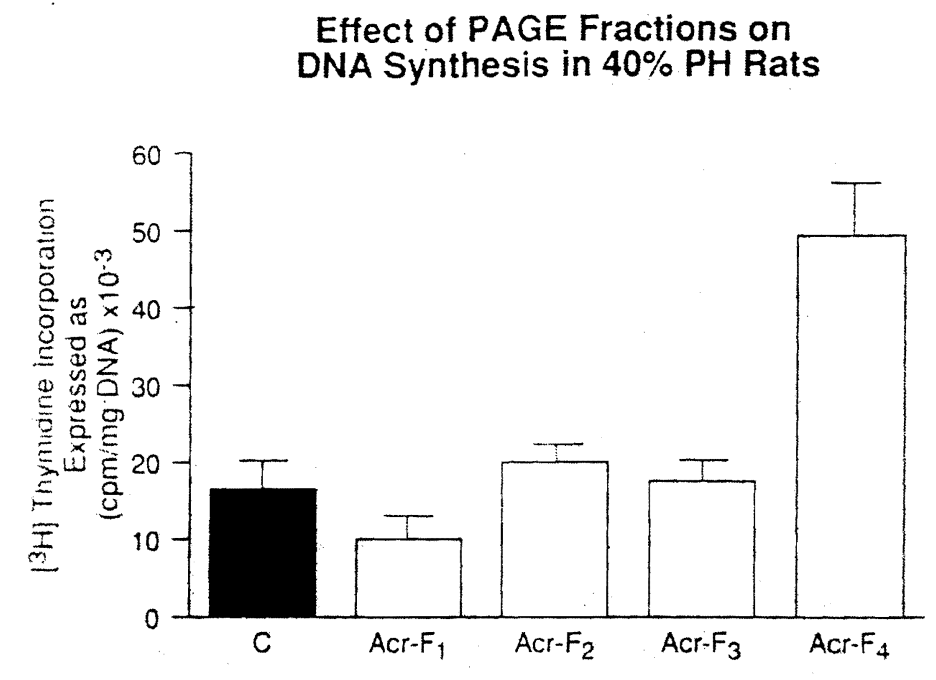

F150 Native PAGE

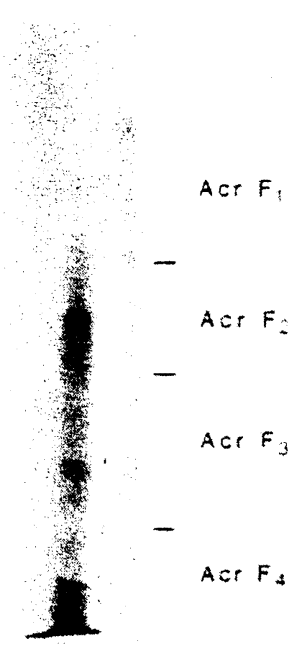

FiG. 3. Electrophoresis of rat ALR purified 381,000 times, showing augmentation of regeneration (following $40 \%$ hepatectomy), only with acrylamide fraction $4\left(\mathrm{Acr} \mathrm{F}_{4}\right)$.

\section{Dose-Response Effect on Liver Proliferation of Acr-F4 Injected in 40\% Hepatectomized Rats and in the Left Lobe of Dogs with PCS}

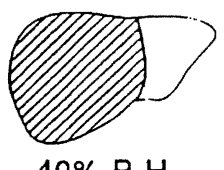

$40 \%$ P.H.
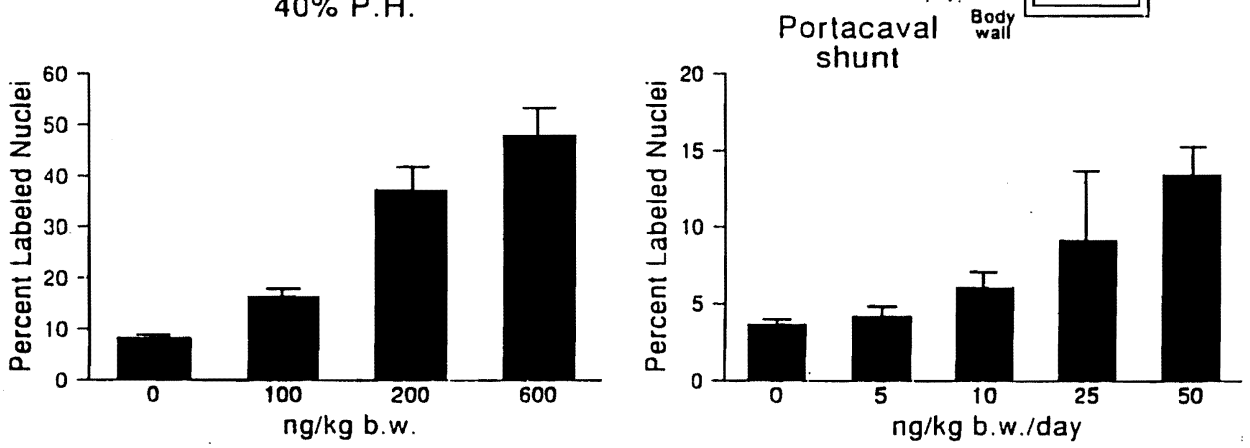

FIG. 4. Correlation of rat ALR ( $A c r F_{4}$ ) effect in rat hepatectomy (left) and canine Eck fistula (right) assays. Note that the doses/kg were 10 times greater or more in the rat than in the dog assay.

tified in a single test dog. Because the effective dose $/ \mathrm{kg}$ in the canine model was $1 / 10$ to $1 / 20$ of that in the rat assay (Fig. 4), the largest total amount needed to test a normal size dog, even with high doses, was <500 ng.

A murine monoclonal antibody raised against $\mathrm{Acr}_{4}$ and added to $\mathrm{AcrF}_{4}$ in the Eck fistula infusate eliminated the activity contained in this fraction, while having no effect on the hepatotrophic activity of IGF II or hepatocyte growth factor (HGF) (Table 4). The same monoclonal antibody was useful to further demonstrate the specificity of the later $\times 831,000$ purification product, which had an estimated molecular weight of $33 \mathrm{kDa}$ (16).
At the end, the activity of recombinant ALR was similarly cancelled by this antibody (see later text).

Cloning of ALR. In June 1989, a meeting in Pittsburgh with officials of the Toyobo Corporation, Osaka, Japan, was arranged by Dr. Yuichi Iwaki, Professor of Surgery, University of Pittsburgh. The first shipment of the purified rat ALR was sent to Japan in March 1990. The fraction (Acr $\mathrm{F}_{4}$ ) (Fig. 3) contained three residual bands of 14,30 and $35 \mathrm{kDa}$, as well as a band of thioredoxin. Its characteristics are summarized in Table 5. The procedures had involved the following successive steps: ethanol precipitation, ultrafiltration through an 
TABLE 4. Specific activity of mAb against native ALR tested in the Eck fistula model ${ }^{a}$

\begin{tabular}{|c|c|c|c|c|}
\hline \multirow[b]{2}{*}{ Dog no. } & \multirow[b]{2}{*}{ Infusate } & \multirow[b]{2}{*}{ Side infused } & \multicolumn{2}{|c|}{ Labelled hepatocytes (per thousand) } \\
\hline & & & Left & Right \\
\hline 1 & HGF $50 \mathrm{ng} / \mathrm{kg} /$ day & Left & $12.0 \pm .01$ & $4.7 \pm 0.12$ \\
\hline 3 & IGF II, $50 \mathrm{ng} / \mathrm{kg} /$ day & Left & $12.2 \pm .01$ & $4.37 \pm 0.51$ \\
\hline 4 & IGF II, 50 ng/kg/day $\mathrm{mAb}^{+}$ & Right & - & 11.1 \\
\hline 5 & Acr $\mathrm{F}_{4} 50 \mathrm{ng} / \mathrm{kg} /$ day & Left & 13.8 & - \\
\hline
\end{tabular}

${ }^{a}$ Infusions for 4 days immediately after the completely diverting portacaval shunt.

Amicon PM30 membrane, cation-exchange FPLC on a Mono Q column and nondissociating PAGE. The amino acid sequence was not yet known.

The $30-\mathrm{kDa}$ band was sliced from the gel after being stained with Coomassie Brilliant blue, digested with lysil endopeptidase (Achromobacter lyticus protease I) and separated with ODS column. A full-length cDNA clone was found encoding this purified native ALR. The $1.2 \mathrm{~kb}$ cDNA included a 299-bp 5' untranslated region, a 375-bp coding region, and a 550-bp $3^{\prime}$ untranslated region. It encoded a protein consisting of 125 amino acids. The molecular weight of ALR calculated from the cDNA was 15,081 , which was consistent with the size estimated by SDS-PAGE under the reducing condition. The molecular weight of the purified native ALR, estimated by SDS-PAGE under the nonreducing condition, was about 30,000 , apparently with a homodimer structure. After transfection of the clone into mammalian COS cells, recombinant rat ALR with 125 amino acids was produced (Fig. 5). This achievement is described fully elsewhere (17).

Testing of Recombinant ALR. After the ALR expression vector was transfected into COS cells, its peptide product was looked for in separately collected supernatant and the cytosolic fraction of COS cell homogenate. Both collections were tested in the Eck fistula model as well as the Vector-COS cytosol and supernatant, which contained no activity (negative controls) (Table 6). Recombinant HGF (65), which was previously shown to be hepatotrophic in the Eck fistula model (18), was used as positive control (Table 6).

A dose-dependent stimulation of DNA synthesis was detected only in the cytosolic fraction (dogs 5 and 6, Table 6), but not in the culture supernatant ( $\operatorname{dog} 4$, Table 6). This effect on the Eck fistula liver was abolished by the same anti-ALR monoclonal antibody (dog 6 , Table 6) that had been used earlier (Table 4) to determine the specificity of the native ALR, including the most highly purified fraction for which the molecular weight had been preliminarily estimated to be $33 \mathrm{kDa}(16)$.

The recombinant ALR prevented the characteristic hepatocyte atrophy of Eck fistula on the treated side of the liver but not the other (Table 6), an effect also cancelled by the anti-ALR monoclonal antibody (dog 6). The ultrastructure of the protected hepatocytes was normal, whereas hepatocytes in the control (untreated) region of liver showed the typical damage caused by Eck's fistula.
TABLE 5. Augmentation of liver regeneration

\begin{tabular}{ll}
\hline Physicochemical characteristics & \\
\hline Heat & Stable $>70^{\circ} \mathrm{C}$ \\
pH resistance & 4.5 to 7.5 \\
Neuraminidase & Resistant \\
Trypsin & Destroyed \\
SDS & Resistant \\
Reducing agents & Resistant \\
Immunogenicity & Yes \\
Species & Nonspecific \\
Organ & Nonspecific \\
\hline
\end{tabular}

ALR mRNA in rat tissues was examined by Northern hybridization with the entire coding region as a probe. Rat ALR mRNA is expressed in most tissues (heart, brain, spleen, lung, liver, skeletal muscle and kidney) in relatively low abundance, but in high abundance in the testis (17). The size of mRNA of ALR is about $1.2 \mathrm{~kb}$, the same as the cDNA.

\section{Other Nonhormonal Growth Factors Detected with the Eck Fistula Assay}

IGF II, TGF- $\alpha$ and HGF also have been demonstrated with the Eck fistula assay to have hepatotrophic qualities similar to those of insulin (18). EGF was almost inert in the Eck fistula model, in spite of its known mitogenic qualities in hepatocyte tissue culture (41), and its chemical similarity to TGF- $\alpha$, with which it has a common cell surface receptor (66). Of the potent hepatotrophic substances, only TGF- $\alpha$ and HGF are mitogenic in tissue culture (Table 1). Several other molecules that are mitogenic in tissue culture were inactive in the Eck fistula model.

\section{Hepatotrophic Immunosuppressants}

Cyclosporine and FK 506. These two chemically unrelated drugs, which have in common the prevention of transcription of early T-cell activation genes, augment posthepatectomy regeneration $(67,68)$ and are potently hepatotrophic in the Eck fistula assay $(19,20)$. They also have similar renal and neurologic side effects and are diabetogenic (69). How two such seemingly diverse agents could have similar pleiotropic actions was reconciled by the discovery that both are inherently inactive "prodrugs" that bind to biologically "inert" cytosolic immunophilins. Although the immunophilin for each 


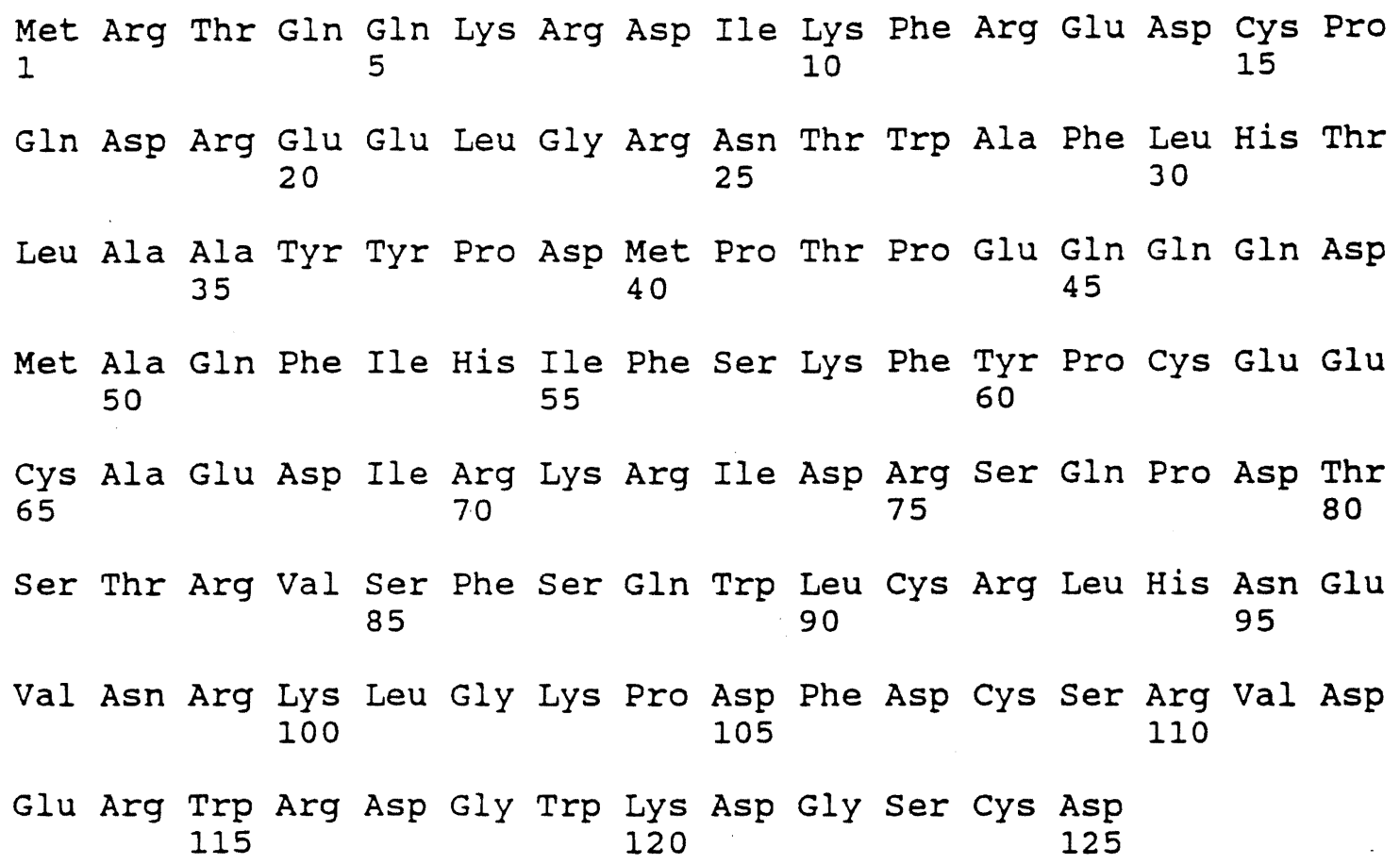

FIG. 5. The amino acid sequence of rat ALR protein. This was deduced from the cDNA nucleotide sequence. Details in reference 17.

TABLE 6. Tests in the Eck fistula assay ${ }^{\infty}$

\begin{tabular}{|c|c|c|c|c|c|c|}
\hline Dog no. & Infusate & Side infused & \multicolumn{2}{|c|}{$\begin{array}{l}\text { Hepatocyte size } \\
\text { (size units) }\end{array}$} & \multicolumn{2}{|c|}{$\begin{array}{l}\text { Labelled hepatocytes } \\
\text { (per thousand) }\end{array}$} \\
\hline 1 & HGF Supernatant ${ }^{b}$ & Left & 0.156 & 0.088 & 11.0 & 5.3 \\
\hline 3 & Vector-COS Supernatant (NC) & Left & 0.103 & 0.101 & 3.8 & 4.0 \\
\hline 4 & ALR-26 Supernatant (40 ng/kg) & Left & 0.079 & 0.103 & 6.4 & 6.6 \\
\hline 5 & ALR-26 Cytosol (40 ng/kg) & Left & 0.163 & 0.090 & 15.2 & 4.8 \\
\hline
\end{tabular}

${ }^{a}$ Infusions for 4 days immediately after the completely diverting portacaval shunt.

${ }^{b} \mathrm{HGF}$ : Human hepatocyte growth factor cDNA expression vector (del-HFG) was used for transfection (65). HGF previously was shown to be hepatotrophic (18), and this was a positive control of the assay.

NC, negative control.

drug has a different molecular weight, the cyclosporinecyclophilin and FK 506-FKBP complexes activate a common target, phosphatase calcineurin, which modifies the transduction of signals from the surface T-cell receptor to the nucleus (70). The immunophilins are found in all cells and are suspected by related mechanisms to modulate multiple endocrinologic, immunologic, growth control and chaperone-mediated pathways (71-73).

A Hepatotrophic Immunophilin. The possible existence of endogenous (natural) ligand(s) for the immunophilins has been raised by the demonstration that the inert recombinant $\mathrm{FKBP}_{12}$ has dose-dependent hepatotrophic activity when tested in vivo with the Eck fistula assay (21). Identification of such a ligand would permit study of at least one natural function of the immunophilins that are present in essentially all cells.
With the addition of $\mathrm{FKBP}_{12}$, the list of hepatotrophic agents had grown to eight (Table 1).

\section{Antihepatotrophic Factors}

The Eck fistula assay also has identified two growthinhibitory (antihepatotrophic) factors that make the atrophy of the Eck fistula liver more extreme and inhibit its characteristic low-grade hyperplasia.

$T G F-\beta$. The growth factor/cytokine, TGF- $\beta$, is pharmacologically specific in that it cancels the hepatotrophic activity of coadministered TGF- $\alpha$, while having no effect on coadministered insulin, IGF II, HGF, FK 506 or ALR (22).

RPM. This potent, T-cell-directed immunosuppressant is closely related chemically to FK 506 and complexes with the same immunophilin (70). However, it has an opposite growth effect, being dramatically 
antihepatotrophic (23). The RPM-FKBP ${ }_{12}$ complexes, unlike those formed by cyclosporine and FK 506, do not affect the phosphatase calcineurin, but prevent the phosphorylation of an S6 kinase $(70,000)$ proximal to the ribosomes (74). Thus, RPM is immunosuppressive far downstream from the inhibition of nuclear transcription of FK 506 and cyclosporine, acting instead by preventing the action of $\mathrm{IL}_{2}$ and other cytokines after their production $(75,76)$. In tissue culture, RPM selectively reduces the gene expression of TGF- $\beta$ (77).

\section{ALR IN THE GROWTH FACTOR UNIVERSE}

Only after the testing of the recombinant ALR could we be sure that it was a unique growth factor. The cDNA has 50\% homology with nuclear gene ERV1 of "baker's" yeast, Saccharomyces cerevisiae (26). This is one of the few dual-function nuclear genes that is not only part of the mitochondrial respiratory chain, but also plays an independent critical role in cell growth regulation. Although yeasts can survive as "petite mutants" without oxidative phosphurylation (78), deletion of the ERV1 gene causes a severe growth defect, decline of mitosis in less than $24 \mathrm{hr}$ and irreversible cessation of cell division after 3 to 4 days (26). The ALR gene is suspected to be the mammalian homolog of the ERV1 gene.

It was previously thought that ALR was liver specific, but the variable RNA expression in nonhepatic tissues, particularly the testis (17), suggests that ALR can be expressed by other mitotically active cells. The effects of this peptide, like those of the other seven growth factors identifiable with the Eck fistula model, go beyond the augmentation of hepatocyte proliferation and maintenance of cell size. All eight prevent disruption of the rough endoplasmic reticulum, mitochondria and other organelles. It is possible that these essentially identical end points are reached by common intermediary molecular mechanisms involving ALR. Because ALR apparently is a delayed product of, not an initiator of, regeneration, the ALR gene could be a growth-regulatory gene, controlling and integrating the activities of other genes by modulating the production or use of their mRNAs.

Nowhere is the need for such gene cross-regulation more clearly illustrated than by liver regeneration, with its bewildering profile of multiple gene activation (79). Without this context introduced by Jacob and Monod (80), it is impossible to envision how the long list of factors (many nonspecific) that can promote or initiate mitotic activity of hepatocytes in tissue culture (46, 81-84) could result in coherent growth or regeneration responses. A regulatory role also has been suggested for insulin $(85,86)$.

The complexity of regeneration and the consequent difficulty of drawing conclusions about individual growth factors from the effects of their isolated administration in vivo or their addition to hepatocyte tissue culture has been emphasized often by us $(18,59)$ and recently by Webber et al. (87). The value of the Eck fistula assay appears to be that it can identify genuinely important growth-related gene products or agents that influence their production and action within a much larger collection of potential growth candidate substances screened with tissue culture techniques.

Although their regulation is incompletely understood, four of the other seven known hepatotrophic substances (insulin, IGF II, TGF- $\alpha$ and HGF) and one antihepatotrophic molecule (TGF- $\beta$ ) bind to specific cell membrane receptors and become internalized tyrosine kinases by autophosphorylation in the first step of signal transduction to the nucleus by means of further phosphorylation targets at tyrosine, serine and threonine sites (88). Although two of the remaining three (cyclosporine, FK 506) as well as the antihepatotrophic immunosuppressant RPM have cytosolic binding sites, their ultimate effect also is thought to be alteration of signal transduction (see earlier text).

It remains to be seen what variation (if any) of these patterns is followed by ALR. The Eck fistula assay experiments, which revealed no activity in the culture medium of COS cell transformant, showed that the ALR had remained in the cells. Because ALR lacks a stretch of hydrophobic amino acids, either N-terminal or internal, that could act as a signal sequence, it is not clear how ALR is transported across the membrane of the endoplasmic reticulum and is secreted. However, it is possible that ALR is secreted through a novel pathway, as has been suggested for IL-1B and thioredoxin, which may involve translocation of intracellular membranes, rather than the classic ER-Golgi route (89), depending on the cell types.

Of the eight known hepatotrophic agents, only HGF and TGF- $\alpha$ unequivocally stimulate hepatocytes to mitosis in culture. Because ALR belongs to the nonstimulator group, its powerful growth effects on hepatocytes in vivo may be through the regulation of nonparenchymal cells. If so, this will be a key link with leukocytes of the immune system of the kind recently made with insulin (86). A longstanding hypothesis of immunological modulation of liver regeneration by nonparenchymal cells $(90,91)$ has been supported by the recent observation that the onset and termination of the wave of hepatocyte mitosis in the regeneration process correlates with the down- and up-regulation, respectively, of MHC Class II antigens in antigen-presenting cells and the consequent regulation (through lymphocytes) of gamma IFN, Il1 and other cytokines (92). If a connection is made between ALR amongst other growth factors and leukocyte function, the growth stimulatory and inhibitory effects of cyclosporine, FK 506 and RPM on the liver will be investigated with renewed interest.

Acknowledgment: We thank the Pittsburgh Cancer Institute Hybridoma Facility and Dr. Albert B. DeLeo for preparing the monoclonal antibody used in these experiments.

\section{REFERENCES}

1. Meyer WH Jr, Starzl TE. The effect of Eck and reverse Eck fistula in dogs with experimental diabetes mellitus. Surgery 1959;45: 760-764.

2. Starzl TE, Butz GW Jr, Meyer WH Jr, Torok EE, Dolkar RE. 
Effect in dogs of various portal vein shunts on response to insulin. Am J Physiol 1962;203:275-277.

3. Starzl TE, Scanlan WA, Thornton FH, Wendel RM, Stearn B, Lazarus RE, McAllister W, Shoemaker WC. Effect of insulin on glucose metabolism in the dog after portacaval transposition. Am J Physiol 1965;209:221-226.

4. Hahn M, Massen O, Nencki M, Pavlow J. Die Eck'sche Fistel zwischen der unteren Hohlvene und der Pfortader und ihre Folgen fur den Organismus. Arch Exp Path Pharm 1893;32:161-210.

5. Bollman JL. The animal with an Eck fistula. Physiol Rev 1961;41:607-621.

6. Starzl TE, Kaupp HA Jr, Brock DR, Lazarus RE, Johnson RV. Reconstructive problems in canine liver homotransplantation with special reference to the postoperative role of hepatic venous flow. Surg Gynecol Obstet 1960;111:733-743.

7. Starzl TE, Marchioro TL, Rowlands DT Jr, Kirkpatrick $\mathrm{CH}$, Wilson WEC, Rifkind D, Waddell WR. Immunosuppression after experimental and clinical homotransplantation of the liver. Ann Surg 1964;160:411-439.

8. Marchioro TL, Porter KA, Dickinson TC, Faris TD, Starzl TE. Physiologic requirements for auxiliary liver homotransplantation. Surg Gynecol Obstet 1965;121:17-31.

9. Marchioro TL, Porter KA, Brown BI, Otte J-B, Starzl TE. The effect of partial portacaval transposition on the canine liver. Surgery 1967;61:723-732.

10. Starzl TE, Francavilla A, Halgrimson CG, Francavilla FR, Porter $\mathrm{KA}$, Brown TH, Putnam CW. The origin, hormonal nature, and action of hepatotrophic substances in portal venous blood. Surg Gynecol Obstet 1973;137:179-199.

11. Starzl TE, Porter KA, Putnam CW. Intraportal insulin protects from the liver injury of portacaval shunt in dogs. Lancet $1975 ; 2: 1241-1246$

12. Starzl TE, Jones AF, Terblanche J, Usui S, Porter KA, Mazzoni G. Growth-stimulating factor in regenerating canine liver. Lancet $1979 ; 1: 127-130$

13. Francavilla A, Ove P, Wu SK, DiLeo A, Van Thiel D, Starzl TE. Extraction of hepatic stimulatory activity (HSA) from (adult) rat liver following T3 injection (Abstract). HEPATOLOGY 1982;2:704.

14. Francavilla A, Ove P, Polimeno L, Coetzee M, Makowka L, Rose J, Van Thiel DH, Starzl TE. Extraction and partial purification of hepatic stimulatory substance in rats, mice and dogs. Cancer Res 1987;47:5600-5605.

15. Francavilla A, Barone M, Van Thiel DH, Mazzaferro V, Prelich J, Starzl TE. Further steps of HSS (hepatic stimulatory substance) purification. Dig Dis Sci 1991;36:674-680.

16. Francavilla A, Polimeno L, Barone M, Azzarone A, Starzl TE. Hepatic regeneration and growth factors. J Surg Oncol 1993; 3(suppl):1-7.

17. Hagiya M, Francavilla A, Polimeno L, Thara I, Sakai H, Seki T, Shimonishi M, Porter K, Starzl TE. Cloning and sequence analysis of the rat augmenter of liver regeneration (ALR) gene: expression of biologically active recombinant ALR and demonstration of tissue distribution. Proc Natl Acad Sci U S A 1994;91:8142-8146.

18. Francavilla A, Starzl TE, Porter K, Scotti-Foglieni C, Michalopoulos GK, Carrieri G, Trejo J, et al. Screening for candidate hepatic growth factors by selective portal infusion after canine Eck fistula. HEPATOLOGY 1991;14:665-670.

19. Mazzaferro V, Porter KA, Scotti-Foglieni CL, Venkataramanan R, Makowka L, Rossaro L, Francavilla A, et al. The hepatotrophic influence of cyclosporine. Surgery 1990;107:533-539.

20. Starzl TE, Porter KA, Mazzaferro V, Todo S, Fung J, Francavilla A. Hepatotrophic effects of FK 506 in dogs. Transplantation 1991;51:67-70.

21. Starzl TE, Schrieber SL, Albers MW, Porter KA, Foglieni CS, Francavilla A. Hepatotrophic properties in dogs of human FKBP, the binding protein for FK 506 and rapamycin. Transplantation 1991:52:751-753.

22. Francavilla A, Azzarone A, Carrieri G, Scotti-Foglieni C, Zeng QH, Cillo V, Porter K, Starzl TE. The effect on the canine Eck fistula liver of intraportal TGF-Beta alone or with hepatic growth factors. HEPATOLOGY 1992;16:1267-1270.

23. Francavilla A, Starzl TE, Scotti C, Carrieri C, Azzarone S, Zeng DH, Porter KA, Schreiber S. Inhibition of liver, kidney and intestine regeneration by rapamycin. Transplantation 1992;53: 496-498.

24. Eck NV. K voprosu o perevyazkie vorotnois veni: Predvaritelnoye soobschjenye. Voen Med J 130:1-2, 1877. (Translation: Ligature of the portal vein). Child C.G. III: Surg Gynecol Obstet 1953;96: 375-376.

25. Welch CS. A note on transplantation of the whole liver in dogs. Transplant Bull 1955;2:54.

26. Lisowsky T. Dual function of a new nuclear gene for oxidative phosphorylation and vegetative growth in yeast. Mol Gen Genet 1992;232:58-64.

27. Morstyn G, Burgess AW. Hemopoietic growth factors: A review. Cancer Res 1988;48:5624-5637.

28. Moore MAS. Clinical implications of positive and negative hematopoietic stem cell regulators. Blood 1991;78:1-19.

29. Lieschke GJ, Burgess AW. Granulocyte colony-stimulating factor and granulocyte-macrophage colony-stimulating factor. N Engl J Med Part I 1992;327:28-35; Part II 1992;327:99-106.

30. Wu GY, Wilson JM, Shalaby F, Grossman M, Shafritz DA, Wu CH. Receptor-mediated gene delivery in vivo. Partial correction of genetic analbuminemia in Nagase rats. J Biol Chem 1991;266: 1438-42.

31. Starzl TE, Lee IY, Porter KA, Putnam CW. The influence of portal blood upon lipid metabolism in normal and diabetic dogs and baboons. Surg Gynecol Obstet 1975;140:381-396.

32. Putnam CW, Porter KA, Starzl TE. Hepatic encephalopathy and light electron micrographic changes of the baboon liver after portal diversion. Ann Surg 1976;184:155-161.

33. Starzl TE, Porter KA, Francavilla A. The Eck fistula in animals and humans. Curr Probl Surg 1983;20:687-752.

34. Starzl TE, Watanabe K, Porter KA, Putnam CW. Effects of insulin, glucagon, and insulin/glucagon infusions on liver morphology and cell division after complete portacaval shunt in dogs. Lancet 1976;1:821-825.

35. Rubin E, Gevirtz NR, Cohan P, Tomita F, Jacobson JH. Liver cell damage produced by portacaval shunt. Proc Soc Exp Biol Med 1965;118:235.

36. Starzl TE, Porter KA, Kashiwagi N, Putnam CW. Portal hepatotrophic factors, diabetes mellitus and acute liver atrophy, hypertrophy and regeneration. Surg Gynecol Obstet 1975;141: 843-858

37. Oudea P, Bismuth H. L'Anastomose porto-cave experimentale chez le rat normal. Pathol Biol 1965;13:288.

38. Mallet-Guy Y, Hezez G, Feroldi J. Anastomose portocave laterolaterale experimentale. Documents histologiques et electro-microscopiques. Lyon Chir 1972;68:436.

39. Starzl TE, Porter KA, Kashiwagi N, Lee IY, Russell WJI, Putnam $\mathrm{CW}$. The effect of diabetes mellitus on portal blood hepatotrophic factors in dogs. Surg Gynecol Obstet 1975;140:549-562.

40. Gerschenson LE, Okigaki T, Anderson M, Molson J, Davidson MB. Fine structural and growth characteristics of cultured rat liver cells: insulin effects. Exp Cell Res 1972;71:49-58.

41. Richman RA, Claus TH, Pilkes SJ, Friedman DL. Hormonal stimulation of DNA synthesis in primary cultures of adult rat hepatocytes. Proc Natl Acad Sci U S A 1976;73:3589-3592.

42. Bernaert D, Wanson J-C, Drochmans P, Popowski A. Effect of insulin on ultrastructure and glycogenesis in primary cultures of adult rat hepatocytes. J Cell Biol 1977;74:878-900.

43. Starzl TE, Francavilla A, Porter KA, Benichou J, Jones AF. The effect of splanchnic viscera removal upon canine liver regeneration. Surg Gynecol Obstet 1978;147:193-207.

44. Starzl TE, Francavilla A, Porter KA, Benichou J. The effect upon the liver of evisceration with or without hormone replacement. Surg Gynecol Obstet 1978;146:524-531.

45. Short J, Brown RF, Husakova A, Gilbertson JR, Zemel R, Lieberman I. Induction of deoxyribonucleic acid synthesis in the liver of the intact animal. J Biol Chem 1972;247:1757-66.

46. Leffert H, Alexander NM, Faloona G, Rubalcava B, Unger R. Specific endocrine and hormonal receptor changes associated with liver regeneration in adult rats. Proc Natl Acad Sci U S A 1975; 72:4033-4036.

47. Holley RW. Control of growth of mammalian cells in cell culture. Nature 1975;258:487-490. 
48. Bucher NLR, Swaffield MN. Regulation of hepatic regeneration in rats by synergistic action of insulin and glucagon. Proc Natl Acad Sci US A 1975;72:1157-1160.

49. Michalopoulos G, Cianciulli HD, Novotny AR, Kligerman AD, Strom SC, Jirtle RL. Liver regeneration studies with rat hepatocytes in primary culture. Cancer Res 1982;42:4673-4682.

50. Nakamura $T$, Nawa $K$, Ichihara $A$. Partial purification and characterization of hepatocyte growth factor from serum of hepatectomized rats. Biochem Biophys Res Commun 1984;122: 1450-1459.

51. Starzl TE, Terblanche J. Hepatotrophic substances. In: Popper H, Schaffner F, eds. Progress in liver diseases, Vol. 6. New York: Grune and Stratton, 1979:135-152.

52. Higgins GM, Anderson RM. Experimental pathology of liver. I. Restoration of the liver of the white rat following partial surgical removal. Arch Pathol 1931;12:186-202.

53. McJunkin FA, Breuhaus HC. Homologous liver as a stimulus to hepatic regeneration. AMA Arch Pathol 1931;12:900-908.

54. Teir H, Ravanti K. Mitotic activity and growth factors in the liver of the whole rat. Exp Cell Res 1953;5:500-507.

55. Blomquist $\mathrm{K}$. Growth stimulation in the liver and tumor development following intraperitoneal injections of liver homogenates in the rat. Acta Pathol Microbiol Scand 1957;121:121.

56. LaBrecque DR, Pesch LA. Preparation and partial characterization of hepatic regenerative stimulator substance (HSS) from rat liver. J Physiol 1975;248:273-284.

57. Terblanche J, Porter KA, Starzl TE, Moore J, Patzelt L, Hayashida N. Stimulation of hepatic regeneration after partial hepatectomy by infusion of a cytosol extract from regeneration dog liver. Surg Gynecol Obstet 1980;151:538-544.

58. Francavilla A, Porter KA, Benichou J, Jones AF, Starzl TE. Liver regeneration in dogs: morphologic and chemical changes. J Surg Res 1978;25:409-419.

59. Starzl TE, Porter KA, Terblanche J. Inter-organ communications: with particular reference to hepatotrophic factors and intrinsic liver growth factors. In: Popper H, Gudat F, Bianchi L, Reutter W, eds. Communications of Liver Cells Proceedings of Falk-Symposium No. 27. Lancaster, UK: PTP Press LTD, 1980:93-97.

60. Francavilla A, DiLeo A, Polimeno L, Gavaler J, Pellicci R, Todo S, Kam I, et al. The effect of hepatic stimulatory substance isolated from regenerating hepatic cytosol and 50,000 and 30,000 subfractions in enhancing survival in experimental acute hepatic failure in rats treated with d-Galactosamine. HEPATOLOGY 1986;6:13461351.

61. Francavilla A, Ove P, Van Thiel D, Coetzee ML, Wu SK, DiLeo A, Starzl TE. Induction of hepatocyte stimulating activity by $T_{3}$ and appearance of the activity despite inhibition of DNA synthesis by adriamycin. Horm Metabol Res 1984;16:237-242.

62. LaBrecque DR, Steele G, Fogerty S, Wilson M, Barton J. Purification and physical-chemical characterization of hepatic stimulator substance. HEPATOLOGY 1987;7:100-106.

63. LaBrecque DR, Suksang C, Guillaumee D. Purification of hepatic stimulator substance(ss) to homogeneity [Abstract]. HEPATOLOGY 1991;14:128A.

64. Fleig WE, Hoss G. Partial purification of rat hepatic stimulator substance and characterization of its action on hepatoma cells and normal hepatocytes. HEPATOLOGY 1989;9:240-248.

65. Matsumoto $\mathrm{K}$, Takehara $\mathrm{T}$, Inoue $\mathrm{H}$, Hagiya $M$, Shimizu $\mathrm{S}$, Nakamura T. Deletion of kringle domains or the N-terminal hairpin structure in hepatocyte growth factor results in marked decreases in related biological activities. Biochem Biophys Res Comm 1991;181:691-699.

66. Marquardt H, Hunkapiller MW, Hood LE, Todaro GJ. Rat transforming growth factor type I: structure and relation to epidermal growth factor. Science 1984;223:1079-1082.

67. Makowka L, Svanas G, Esquivel CO, Venkataramanan R, Todo S, Iwatsuki S, Van Thiel D, Starzl TE. The effect of cyclosporine on hepatic regeneration. Surg Forum 1986;37:353-354.

68. Francavilla A, Barone M, Todo S, Zeng Q, Porter KA, Starzl TE. Augmentation of rat liver regeneration by FK 506 compared with cyclosporine. Lancet 1989;1:1248-1249.

69. Starzl TE, Fung JJ. Contempo 90: Transplantation. JAMA 1990; 263:2686-2687.
70. Schreiber SL, Crabtree GR. The mechanism of action of cyclosporin A and FK 506. Immunol Today 1992;13:136-142.

71. Schreiber SL. Chemistry and biology of the immunophilins and their immunosuppressive ligands. Science 1991;251:283287.

72. Callebaut I, Renoir JM, Lebeau MC, Massol N, Burny A, Baulieu EE, Mornon JP. An immunophilin that binds $M_{r} 90,000$ heat shock protein: Main structural features of a mammalian p59 protein. Proc Natl Acad Sci U S A 1992;89:6270-6274.

73. Xu Q, Leiva MC, Fischkoff MK, Handschumacher RE, Lyttle CR. Leukocyte chemotactic activity of cyclophilin. J Biol Chem 1992;267:11968-11971.

74. Chung J, Kuo J, Crabtree GR, Blenis J. Rapamycin-FKBP specifically blocks growth-dependent activation of and signaling by the $70 \mathrm{kd}$ S6 protein kinases. Cell 1992;69:1227-1236.

75. Dumont FJ, Staruch MJ, Koprak SL, Melino MR, Sigal NH. Distinct mechanisms of suppression of murine T cell activation by the related macrolides FK 506 and rapamycin. J Immunol 1990;144:251-258.

76. Bierer BE, Mattila PS, Standaert RF, Herzenberg LA, Burakoff SJ, Crabtree G, Schreiber SL. Two distinct signal transmission pathways in $\mathrm{T}$ lymphocytes are inhibited by complexes formed between an immunophilin and either FK506 or rapamycin. Proc Natl Acad Sci U S A 1990;87:9231-9235.

77. Francavilla A, Carr B, Starzl TE, Azzarone A, Carrieri G, Zeng QH. Effects of rapamycin (RPM) on cultured hepatocyte proliferation and gene expression. HEPATOLOGY 1992;15:871-877.

78. Grivell LA. Nucleo-mitochondrial interaction in yeast mitochondrial biogenesis. Eur J Biochem 1989;182:477-493.

79. Mohn K, Laz TM, Hsu J-C, Melby AE, Bravo R, Taub R. The immediate early-growth response in regenerating liver and insulin-stimulated $\mathrm{H}-35$ cells; comparison with serum-stimulated 3T3 cells and identification of 41 novel immediate-early genes. Mol Cell Biol 1991;11:381-390.

80. Jacob F, Monod J. Genetic regulatory mechanisms in the synthesis of proteins. J Mol Biol 1961;3:318-356.

81. Leffert HL, Koch KS. Proliferation of hepatocytes. In: Symposium on Hepatotrophic Factors. CIBA Foundation Symposium 1978; 55:61-94.

82. Michalopoulos GK. Liver regeneration: molecular mechanisms of growth control. FASEB J 1990;4:176-187.

83. Francavilla A, Starzl TE, Van Thiel DH, Barone M, Polimeno L. Regeneration. In: Lebouton AV, ed. Molecular and cell biology of the liver. Boca Raton, FL: CRC Press, 1993:309-346.

84. Fausto N. Hepatic regeneration. In: Zakim D, Boyer TD, eds. Hepatology: a textbook of liver disease. Philadelphia: W.B. Saunders Co., 1990:49-64.

85. Sasaki Y, Zhang XF, Nishiyama M, Avruch J, Wands JR. Expression and phosphorylation of insulin receptor substrate 1 during rat liver regeneration. J Biol Chem 1993;268:3805-3808.

86. Stagsted J, Reaven GM, Hansen T, Goldstein A, Olsson L. Regulation of insulin receptor functions by a peptide derived from a major histocompatibility complex class I antigen. Cell 1990;62: 297-307.

87. Webber EM, Godowski PJ, Fausto N. In vivo response of hepatocytes to growth factors requires an initial priming stimulus. HEPATOLOGY 1994;14:489-497.

88. McCormick F. How receptors turn Ras on. Nature 1993;363: 15-16.

89. Rubartelli A, Bajetto A, Allavena G, Wollman E, Sitia R. Secretion of thioredoxin by normal and neoplastic cells through a leaderless secretory pathway. J Biol Chem 1992;267:24161-24164.

90. Flye MW, Yu S. Augmentation of cell-mediated cytotoxicity following 50\% partial hepatectomy. Transplantation 1990;49:581587.

91. Yoshimura S, Kamada N. Effect of cyclosporin A on liver regeneration following partial hepatectomy in the mouse. Transplant Proc 1989;21:911-912.

92. Sato $\mathrm{Y}$, Tsukada K, Matsumoto $\mathrm{Y}$, Abo T. Interferon-y inhibits liver regeneration by stimulating major histocompatibility complex class II antigen expression by regenerating liver. HEPATOLOGY 1993;18:340-346. 